\title{
THE FARMER'S LAW (NOMOS GEORGIKOS) - SOURCE OF LAW REGULATION AND COLLECTIVE SELF-CONSCIOUSNESS OF RURAL COMMUNITY IN MEDIEVAL BYZANTIUM
}

\author{
Yury Ya. Vin \\ Institute of World History, Russian Academy of Sciences, Moscow, Russian Federation
}

\begin{abstract}
The contemporaries of last centuries of Byzantine history, in the spirit of formed axiological attitudes, showed inexhaustible interest to the rural economy. As a rule, it was aroused as well as, by significant emphasis on the problem of law regulation and management of agricultural production. The Farmer's Law (Nomos Georgikos) is a single legal monument of the Byzantine epoch, reconstituting the picture of communal existence in rural areas. And nowadays the Farmer's Law, as well as other law monuments and acts, represents a reliable source for studying the agriculture and offers opportunity to penetrate deeply into the arrangement of medieval Byzantine village as a center of agrarian production and to reveal original methods of regulation of land relations of communal peasantry. The direct authority of Nomos Georgikos in Late Byzantium is displayed by documentary evidence. This is the decision of Constantinople patriarchate of 1325 on regulation of the privity of two land possessors. So the effect of this decision could be interpolated in the village. For centuries the Farmer's Law Here had served as the legal expression of preimage community tradition, and as the source of law regulation of fellow-villagers relations, as well as realized self-consciousness and collective intentions among the medieval Byzantine peasantry.

Key words: Byzantium, Byzantine law, Farmer's law, Nomos Georgikos, rural community.
\end{abstract}

\section{«ЗЕМЛЕДЕЛЬЧЕСКИЙ ЗАКОН»- ИСТОЧНИК \\ ПРАВОВОГО РЕГУЛИРОВАНИЯ И КОЛЛЕКТИВНОГО САМОСОЗНАНИЯ СЕЛЬСКОЙ ОБЩИНЫ В СРЕДНЕВЕКОВОЙ ВИЗАНТИИ}

\author{
Юрий Яковлевич Вин \\ Институт всеобщей истории РАН, г. Москва, Российская Федерация
}

\begin{abstract}
Аннотация. Современники последних веков византийской истории, в духе сложившихся ранее ценностных ориентиров, питали неиссякаемый интерес к экономике сельского хозяйства. Он сопрягался, как правило, с огромным вниманием к проблеме правового регулирования и управления сельскохозяйственным производством. «Земледельческий закон» (Nomos Georgikos) - единственный правовой памятник византийской эпохи, воссоздающий в системном виде картину общинного бытия деревенской глубинки. «Земледельческий закон» и в наши дни, наравне с другими правовыми памятниками и актами, служит надежным источником изучения сельского хозяйства как такового, предоставляя возможность проникать в сущность обустройства средневекового византийского села как средоточия аграрного производства и раскрывать исконные методы регулирования поземельных отношений общинного крестьянства. «Земледельческий закон» долгие столетия выступал как правовое выражение прообщинной традиции, которая до последних веков существо๘. вания Византии служила источником правового регулирования отношений односельчан и воплощала уровень самосознания и коллективистских интенций средневекового византийского крестьянства. община.

Ключевые слова: Византия, византийское право, «Земледельческий закон», Nomos Georgikos, cельская
\end{abstract}


Сельская община в Византии, как она представляется по «Земледельческому закону», дает отчетливую картину существования независимого крестьянства.

Х. Кэпштейн

Современники последних веков византийской истории, в духе сложившихся ранее ценностных ориентиров, питали неиссякаемый интерес к экономике сельского хозяйства. Он, надо сказать, был отнюдь не отвлеченным, а сопрягался, как правило, с огромным вниманием к проблеме правового регулирования и управления сельскохозяйственным производством. Обращает на себя внимание и тот факт, что сельская община как таковая практически никогда не являлась субъектом законодательных установлений. Она чаще всего становилась объектом правового урегулирования посредством обычного права и нормативного законодательства, о чем свидетельствует давно введенное в научный обиход упомина-

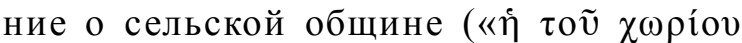

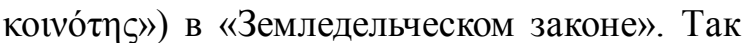
или иначе любое обращение к названному памятнику византийского права побуждает исследователя любого поколения неизбежно вспоминать и о сельской общине. Недаром ее ставили во главу угла авторы многих исследований «Земледельческого закона». Их названия исчисляются даже не сотнями, а тысячами книг, статей и других научных публикаций самых именитых византинистов и правоведов. Дискуссии о происхождении и времени возникновения «Земледельческого закона» и в отечественной, и в зарубежной историографии длятся долгие годы. Правда, современная зарубежная историография преимущественно акцентирует проблемы предназначения «Земледельческого закона» и особенностей преломления в нем традиций римского и византийского права (подробнее см.: [41, p. 180-185]). А наибольший вклад в изучение собственно общинной проблематики этого уникального памятника византийского права внесли отечественные ученые прошлых десятилетий.

Как известно, «Земледельческий закон» сборник правовых норм, регулирующих жизнь сельской общины как самой империи, так и сопредельных с ней регионов, отображает об- щинные порядки в Византии VIII-IX вв. (см.: $[2$, c. 5, 9-25], здесь же указана основная литература). В представлении советских историков и их российских наследников византийская сельская община эпохи «Земледельческого закона» является институтом, объединявшим свободных землевладельцев - непосредственных производителей, мелких собственников земли (см.: [10, с. 118-119; 32, с. 29-30; 31 , с. $9 ; 30$, с. $41-42 ; 25$, с. $17 ; 7$, с. $33-34]$ ). Характерные черты сельской общинной организации обычно видят в совместном владении угодьями, находящимися в нераздельном пользовании ее членов, общности хозяйственных интересов и взаимопомощи общинников (см.: $[37$, с. $19 ; 35$, с. $14 ; 51$, б. 28; 7, с. 34-35; 8 , с. 74-75, 86]). Советские ученые единодушно отрицали проведение в византийской деревне VIII-X вв. периодических переделов, но признавали возможность перераспределения земель, вызванного неудовлетворенностью колонистов результатами первоначального их наделения (см.: [10, с. 119-120; 12, с. 67-69; 32, c. $38-40 ; 5$, с. $31-32,40 ; 14$, с. $102 ; 38$, с. $398-$ 399]). Экономические основы существования сельской общины эпохи «Земледельческого закона», в которой индивидуальное ведение хозяйства сочеталось с общинным выпасом стада, создавали предпосылку для имущественной и социальной дифференциации ее членов. В недрах общины постепенно вызревали условия для перехода обедневшей части общинников в зависимость от зажиточных односельчан и крупных земельных собственников (см.: $[10$, c. $131 ; 12$, с. $74-75,86,127 ; 6$, с. 61-62, 64; 38 , с. $403 ; 7$, с. $35 ; 8$, с. $75 ; 14$, с. $108-109])$.

Среди советских и отечественных ученых не было и нет единого мнения о специфике и особенностях византийской сельской общины эпохи «Земледельческого закона», не сложилось единства и в оценке уровня и форм ее развития. В числе специфических черт общины «Земледельческого закона» называют своеобразное сочетание ее обычаев с римско-византийскими правовыми нормами (см.: $[10$, с. $135 ; 32$, с. $38 ; 6$, с. $50 ; 34$, с. 16$])$. Из общего ряда общинных обычаев исследователи выделяют сохранение «сильно развитых» так называемых прав на чужую землю, то есть права членов общины на невозбранный сбор винограда и фруктов для утоления голода и 
жажды, сенокос и выпас скота на участках соседей (см.: [10, с. 121-122; 6, с. 50 и далее; 5 , с. $35-58,40-41,55 ; 25$, с. $17-18,20,22 ; 34$, c. $16 ; 38$, с. 400]). Однако «Земледельческий закон» не содержит объяснений относительно происхождения «прав» общинников на «чужую землю», в которых видны пережитки позднеримских сервитутов (ср.: [15, с. 17; 38, c. 400]). Что касается уровня, формы и тенденций развития общины в эпоху «Земледельческого закона», то однозначно лишь признание ее дуалистического устройства. Попытка Е.Э. Липшиц представить византийскую общину в качестве самодовлеющей единицы, являющейся опорой бюрократического централизованного государства наподобие восточных деспотий [10, с. 142-143; 12, с. 117-118], вызвала полемику. С точки зрения М.Я. Сюзюмова, отвергавшего азиатский характер византийской сельской общины, она по уровню и формам развития неотличима от западноевропейской марки [32, с. 43-44]. Равным образом общину в период действия «Земледельческого закона» отождествлял с маркой Г.Г. Литаврин [14, с. 102]. Большинство советских и отечественных исследователей подчеркивают отличия византийской сельской общины. Они усматриваются в отношении общинного института раннего и развитого Средневековья, которому приписано, по общему мнению, большее, чем западноевропейской марке, сплочение византийского общинного крестьянства и большая жизнеспособность сельской общины как таковой (см.: [34, с. 16; 33 , с. $8 ; 37$, с. $19 ; 35$, с. $14 ; 51$, б. $29 ; 38$, с. 401 ; 36 , с. $97 ; 50$, p. $133 ; 7$, с. $35 ; 8$, с. 75$]$ ).

Из ряда наиболее заметных трудов прошедших десятилетий, имеющих прямое касательство к проблемам византийской сельской общины, нужно выделить особо критическое издание «Земледельческого закона», предпринятое Е.Э. Липшиц, И.П. Медведевым и Е.К. Пиотровской [2]. Оно безусловно воплотило неоднократно выраженное названными учеными признание «Земледельческого закона» уникальным памятником ранневизантийского права. В их концепции подлинное значение «Земледельческого закона» объясняется исторической ролью свободных крестьянских общин в эпоху становления византийского Средневековья. Е.Э. Лип- шиц и И.П. Медведев характеризуют «Земледельческий закон» как свод правовых норм, регулировавших социально-экономические отношения, сложившиеся в общинной деревне. Главная его особенность усматривается в сочетании обычного эллинистического и варварского права с положениями законодательных кодификаций. Е.Э. Липшиц и И.П. Медведев единодушно подчеркивают близость «Земледельческого закона» наряду с «Военным» и «Морским» законами в «Эклоге» Льва III. Одновременно отмечена востребованность «Земледельческого закона» в византийском праве последующих столетий. Подтверждением тому служит включение большинства статей названного судебника в состав «Эклоги, измененной по Прохирону» («Ecloga ad Prochiron mutate») и многовековая рукописная традиция $[13$, с. $45,201-202 ; 21$, с. 222 ; 18, с. 148 и далее]. В этом смысле предпринятое издание «Земледельческого закона» открывает перед исследователями новые возможности изучения общинных порядков в поздней Византии, поскольку оно воспроизводит конкретные факты использования названного памятника в судопроизводстве той эпохи и доказывает на примере интерполяции текста статьи 81 «Земледельческого закона» сохранение коллективного землевладения в поздневизантийском селе [2, с. 5, 58]. «Земледельческий закон» - единственный памятник византийской эпохи, воссоздающий в системном виде картину общинного бытия деревенской глубинки. Он и в наши дни, наравне с другими правовыми памятниками и актами, служит надежным источником изучения не просто основных направлений экономической политики Византии, а именно сельского хозяйства как такового, предоставляя возможность проникать в сущность обустройства византийского средневекового села как средоточия аграрного производства и раскрывать исконные методы регулирования поземельных отношений общинного крестьянства (подробнее см.: [28, с. 35-81]). «Земледельческий закон» является хрестоматийным примером, который вобрал в себя столетний опыт повседневной жизни раннесредневекового крестьянства эпохи его формирования. В особенности важен вопрос о методах общинного землепользования неподеленными земельными 
участками и находившимися в коллективном распоряжении угодьями (подробнее см.: [28, c. 45 и далее, 63-64]). И потому не случайно, что современный исследователь сельского быта поздневизантийской эпохи обращается к законодательству и прежде всего к «Земледельческому закону», чтобы изучаемые примеры сельскохозяйственного производства сопоставить с запечатленными в названном памятнике типичными казусами правоотношений крестьянства (см.: [45, p. 10, 17-18, 126]; автор этих строк выражает искреннюю благодарность за предоставление указанной книги Н.Д. Барабанову). Ведь без учета воплощенных в статьях «Земледельческого закона» норм обычного права невозможно показать специфику византийского менталитета со свойственными для него социальными установками, которые наполняют правосознание селян последующих веков подлинно самобытными чертами. Непосредственным выражением последнего «Земледельческий закон», несомненно, оставался, наравне с предшествующими временами, и в поздней Византии [39, p. 325]. Это подтверждает вынесенное в 1325 г. на заседании Константинопольского патриархата решение об упорядочивании имущественных отношений двух землевладельцев. Оно оправдывает права одного из них на пользование виноградником, ссылаясь на «местный обычай», который имеет силу «согласно Земледельческому закону» ${ }^{1}$.

Кроме того, видоизмененная версия памятника вошла в приложение к «Шестикнижию» Константина Арменопула (см.: [42, p. XV-XVI; 47, б. $\mu \zeta^{\prime} ; 19$, с. $194 ; 20$, с. 49,68 , 70]. О практической значимости «Земледельческого закона» для юриспруденции поздней Византии см.: [9, с. 1-14; 11, с. 54-59]).

Иначе говоря, «Земледельческий закон» с полным основанием можно отнести к разряду так называемых прецедентных текстов, наделенных ценностной значимостью для различных социальных групп византийцев, для которых предписания этого правового уложения, без сомнения, играли роль своеобразных социокультурных концептов (об обладающих ценностной значимостью прецедентных текстах и их роли для формирования социокультурных концептов подробнее см.: [29, с. 28 и далее]). Недаром воспроизводящие названный памятник и уцелевшие до нашего времени рукописи XIII-XV вв. весьма многочисленны (см.: [20, с. 49-70]). Здесь уместно вспомнить о том, что в раннесредневековый период «Земледельческий закон», наряду с другими правовыми установлениями, такими как «Военный» и «Морской» законы, выступал своеобразным приложением «Эклоги» Льва III. Beроятно, роль названных памятников, и в первую очередь «Земледельческого закона», определялась их предназначением регулировать спорные ситуации, в которых официальное законодательство, как полагает П. Шрайнер, уступало место обычаю [48, S. 585(19)-586(20)]. В то же время уникальность «Земледельческого закона», по мнению Е.Э. Липшиц, обусловливало заимствование его норм из жизненной практики и обычного права варварских, точнее говоря, славянских сельских общин. Представляя собой, согласно характеристике И.П. Медведева, свод правовых норм, регулирующих жизнь сельской общины, «Земледельческий закон» признан юридически состоятельной компиляцией, основанной на сочетании обычного эллинистического и варварского права с положениями законодательных кодификаций. По оценке И.П. Медведева, «Земледельческий закон», адекватно отражавший социально-экономические отношения в крестьянской общине, был ощутимо близок «Эклоге» с точки зрения стилистики и пенальной системы. Подтверждением юридической актуальности, как выразила эту мысль Е.Э. Липшиц - «жизненность норм», «Земледельческого закона» явилось его включение в состав так называемой «Эклоги, измененной по Прохирону». Будучи рассеянными в различных главах названного юридического сборника и дополненными разного рода интерполяциями, многие статьи «Земледельческого закона», тем не менее, не утратили изначальной своей идентичности и заполнили собой лакуны действовавшего законодательства в сфере аграрного строя [13, с. 45, 201-202; 21, с. 222]. При этом нормы византийского «Земледельческого закона» оставили заметный след и в повседневной жизни балканских славян, воспринявших совокупность общинных установлений благодаря переводам и переложениям названного памятника на славянский язык (см.: [24, с. 131 и далее]). Их изучение в последние де- 
сятилетия помимо уяснения особенностей отдельных редакций средневековых рецепций «Земледельческого закона» способствует раскрытию познавательных мотиваций составителей позднейших компиляций (подробнее см.: [27, с. 201-212]; там же указана основная литература).

В соответствии с развертывавшейся тенденцией юриспруденции к систематизации правового наследия поздневизантийские правоведы производят классификацию отдельных статей «Земледельческого закона», расчленяя его текст с помощью титулов. Так в составе древнего судебного сборника появляются, как это удается проследить по рукописной традиции, рубрики «О земледельцах», «О морте», «О половничестве», «О пастухах», «О деревьях», «О мельницах», «О рабах», «О воровстве», «Об ущербе», «О потраве животных», «Об убийстве животных», «О пожаре» и некоторые другие (например, см.: ГИМ. ОР. Рукоп. гр. № 330, л. 272-279; № 329, л. 225234; № 331, л. 282-288; об указанных списках «Земледельческого закона» подробнее см.: [16, с. 227-233]; о титулатуре «Земледельческого закона» также см.: [22, с. 104]). Начатки подобной классификации складываются, что демонстрирует версия «Земледельческого закона», которую отражает его критическое издание, предпринятое К. Феррини, еще в XIII в. (см.: [44, Bd. 7, Hft. 3-4, S. 567-571]; о датировке использованных К. Феррини рукописей см.: [19, с. 195; 2, с. 11]). Деление содержания рукописных версий «Земледельческого закона» на титулы окончательно закрепляется, как показано выше, ко времени составления его так называемой арменопуловской редакции, в основных ее частях восстановленной в публикации Г.Э. Хеймбаха [42, p. 828-851] (об этом также см.: $[19$, c. $194 ; 20$, c. $70 ; 16$, c. $216-$ 228; 2, c. 9]).

Достаточно примечательно то, что в поздней Византии попытки искать ответы на насущные вопросы обустройства сельской жизни делаются на основе документа, заключающего в себе немеркнущее свидетельство о главных устоях общинного уклада, каковым является «Земледельческий закон». В этом свете особое внимание привлекает сохраненное в одной из рукописей поздневизантийского времени пинакс-оглавление названного па- мятника [2, с. 93-95] (о рукописи, воспроизведшей указанный пинакс, подробнее см.: [2, c. 32-33]). Оно не просто подтверждает следование византийцев сложившимся ранее ценностям и стереотипам мышления. О том говорят общие принципы построения оглавления, отдельные пункты которого, как правило, дословно или с определенными расхождениями воспроизводят содержание так называемой гипотезы - первой части правовой нормы, описывающей обстоятельства ее применения соответствующих статей «Земледельческого закона». Показательными оказываются не факты повторения в оглавлении понятийнотерминологических архаизмов, заимствованных из содержания закона, а ярко выраженная тенденция поддерживать сложившиеся общинные порядки, которую нетрудно усмотреть даже в изменениях, внесенных в отдельные пункты пинакса. В числе первых необходимо отметить коррективу названия статьи 31 «Земледельческого закона», посвященной дереву, бросающему тень на соседний земельный участок. Пинакс, как и чтение некоторых других рукописей «Земледельческого закона», вместо упоминаемого здесь в хрестоматийном варианте хорафия распространяет сферу действия данной правовой нормы на «хорион» как таковой (ср.: [2, с. 94, 109]). Описание в пинаксе содержания статьи 42, направленной на предотвращение гибели стада якобы из-за нападения диких животных, более прагматично предупреждает об опасности его угона вместе с одним из волов (ср.: [2, с. 94, 112]). Столь же отчетливо общинной традиции пинакс следует в оглавлении статьи 78. Несмотря на некую несуразицу сделанных здесь изменений, общий смысл статьи - запрет выпускать на чужой земельный участок, когда там еще не снят урожай, своих животных сохранен (ср.: [2, с. 95, 125]). И уже нужно ли много рассуждать о правке названий статей 81 и 82 «Земледельческого закона», если пинакс много столетий спустя после составления названного памятника не только удостоверяет возможность найти «общее место хориона», чтобы сооружать мельницу, или сделать то после раздела территории села на своем собственном наделе? Впрочем, нельзя не подчеркнуть того, что оглавление поздневизантийской компиляции акцентирует в названии ста- 


\section{ИСТОРИЯ, КУЛЬТУРА, ПРАВО В ВИЗАНТИЙСКИХ ПРОВИНЦИЯХ}

тьи 81, а именно факт строительства мельницы «тайком», в то время как «народ» остался о том неосведомлен (ср.: [2, с. 95, 126127]). Допущенное в пинаксе отклонение от описания данного эпизода в тексте «Земледельческого закона», тем не менее, остается в общем русле общинной традиции (подробнее см.: [28, с. 47]). Аналогичный вывод приложим и к запечатленной в названии пинакса версии статьи 84, которая устанавливает правила пользования оросительной системой (ср.: [2, с. 95, 128]).

Характеризуя природу собственности, один из представителей новой ориентации восприятия этого института В.М. Быченков придает большое значение раскрытию субъектных прав каждого члена общины на принадлежавшие ей объекты собственности и владения $[1$, с. 848$]$. Именно такой подход к обсуждаемой проблеме является ключом к достоверному пониманию сути собственнических отношений, которые обнаруживало общинное крестьянство, когда в его патриархальном правосознании выдвигало на первый план в качестве их источника личный труд. Фактически же этому принципу сопутствовала мысль о правах собственности на землю тех, кто ее обрабатывал, и о праве общины контролировать всю систему землепользования $[23$, c. $22-25]$.

На самом деле византийское Средневековье данную дилемму, а стало быть, и вопрос о сущности сельской общины, решало совершенно иначе, нежели римские правоведы и современная юридическая наука. Статья 81 «Земледельческого закона» доказывает, что члены сельской общины стремились сохранять общую собственность неделимой в совместном пользовании [28, с. 47]. Выработанное столетиями отношение к ней было поддержано и в поздневизантийской деревне, о чем неоспоримо свидетельствует использованная редакция текста этой статьи рубежа XIII-XIV вв., которая объявляла изъятие общей земли в частную собственность грубым

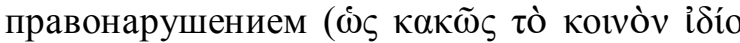

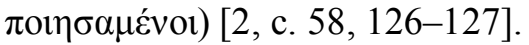

Здесь же отдельные представители сельской общности зачастую получали наименование «кинонос», служившее в качестве названия членов «кинонии»- одного из при- нятых в византийском законодательстве понятий права, служившего для наименования общественных объединений в целом, в частности, профессиональных организаций и правоотношений их членов, тогда как для обозначения сельской общины предлагались в первую очередь понятия «омада» и «кинотис». Бесспорную специфику словоформам «омас» - «омада» и «кинотис» придавало их сочетание со словом «хорион», превращавшее указанные понятия в технические термины. В документах обычно-правового и нормативного происхождения отмеченные понятия становились своего рода титулами сельского селения, с помощью которых происходило видимое изъявление в источниках субъектно-объектного статуса сельской общины. Он предопределялся местом общинной организации села в социальной системе Византийской империи, то есть характером взаимосвязей между сельской общностью и государством. В то же время, как убеждают свидетельства поздневизантийских версий «Земледельческого закона», «Шестикнижия» Константина Арменопула и других памятников права вплоть до последних веков византийской истории, понятия «омас»«омада» и «кинония» не растеряли присущего им изначально содержания, исполненного смыслом «целостности» и «общности». И этот смысл, как и техническая значимость данных словоформ, очевидно, были вполне доступными современникам указанной эпохи [3, с. 145-176].

В указанной связи, конечно, снова требует к себе особого внимания статья 81 «Земледельческого закона», посвященная, как разъяснялось ранее, строительству одним из жителей села мельницы на «общем месте», то есть принадлежавшем или находившемся под контролем и в пользовании всех селян [28, с. 47]. Они, кстати, названы безвестным составителем названного судебника «сотоварищами», буквально - «кинонами», собственно говоря - «членами кинонии». Но упоминаний о последней, что уже было сказано по этому поводу, в «Земледельческом законе» нет, а критическое его издание под редакцией И.П. Медведева исключает из текста статьи 81 этого памятника понятие «кинотис», заменяя его чтением «селяне со- 


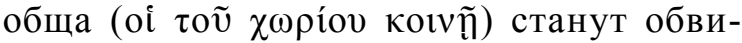
нять...» $[2$, с. 126-127, 176]. Усложнив чтение соответствующего фрагмента указанной статьи, И.П. Медведев сумел наилучшим образом мотивировать свое решение лишь спустя тридцать лет в своем экспертном интервью о «Земледельческом законе» для экспертной системы «Византийское право и акты»: «Этот “кинотис" - это уже более современное осознание той действительности, которая имелась в виду, а раз так, я просто счел себя не вправе, как бы мне ни хотелось, этот термин “община” ввести в основной текст, решил его упомянуть в разночтениях, а не вводить в основной текст... Все-таки сообща хориты, крестьяне деревенские, решают какой-то вопрос сообща - “кини”, но не “кинотис". Община хоритов решает, как там тот или иной вопрос должен решаться. Не “кинотис", не община, а крестьяне сообща между собой договариваются, как этот вопрос должен быть решен. Мне кажется, это как-то даже логичнее» (подробнее см.: [17]. Также см.: [4, с. 55-56]). Тем не менее И.П. Медведев не стал, как следует из экспертного интервью, бесследно элиминировать понятие «кинотис», поскольку оно присутствует в контексте статьи 81 , воспроизводимом целым рядом использованных издателем рукописей «Земледельческого закона» [2, c. 126-127, примеч. Сар. 81]. Согласно опущенному И.П. Медведевым прочтению статьи 81 в ней говорится: «кинотис хориона

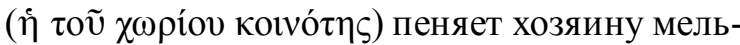
ницы, занявшему общее место как свое...» Именно такой редакции придерживается предыдущий издатель «Земледельческого закона» У. Эшбернер [40, p. 108]. К сказанному надо добавить, что еще за несколько лет до выпуска в свет новой редакции «Земледельческого закона» И.П. Медведев называл приведенное своим предшественником чтение обсуждаемой статьи «нормальным» (см.: [20, c. 52]). Вместе с тем для исследования поздневизантийской общины важно то обстоятельство, что близкий тому вариант данного пассажа воспроизводят и издание К. Феррини, которое, как мы выяснили, опирается на рукописи XIII в. [44, S. 567], и «арменопуловская редакция» «Земледельческого закона» (ср.: [42, p. 850 (Т. Х.6)]). Словом, уже эти примеры адекватно свидетельствуют о том, что представления о сельской общине не только не были чужды поздней Византии, но сущность взаимоотношений односельчан в тот период отождествлялась, как и ранее, с их «общностью» - «кинотисом» - в рамках хориона. И потому не было случайностью, что А.С. Павлов в его переводе указанной статьи «Земледельческого закона» концепт «кинотис хориона» рассматривает как «сельский мир» (см.: [26, с. 29]). В свою очередь А.П. Каждан в одной из последних публикаций, посвященных проблемам византийского села, также по праву отождествляет понятия «Кинон» (коเvóv) или «кинотис хориона» не с каким иным явлением, а именно с сельской общиной [46, p. 75-76].

Таким образом, «Земледельческий закон» долгие столетия выступал как правовое выражение прообщинной традиции, которая до последних веков существования Византии служила источником правового регулирования отношений односельчан и воплощала уровень самосознания и коллективистских интенций средневекового византийского крестьянства.

\section{ПРИМЕЧАНИЕ}

${ }^{1}$ См.: [43. № 93.59-60]. На этот пример некогда - сначала в беседе при личной встрече, а затем, по просьбе И.П. Медведева, сопровожденной обещанием дать ссылку на автора сих строк, и в письме (20 января 1982 г.) с указанием соответствующей страницы издания, правда, Ф. Миклошича и И. Мюллера, - было обращено внимание ответственного редактора еще в период подготовки - задолго до выхода в свет - «Византийского земледельческого закона» [2]. Впоследствии многоуважаемый ученый, видимо, запамятовав о данном обстоятельстве, использовал указанный фрагмент, приведя, к сожалению, неточный перевод соответствующего пассажа (см.: [2, с. 5]). Следует прибавить, что сделанное тут же утверждение И.П. Медведева об упоминании «Земледельческого закона» в одном из писем константинопольского патриарха Афанасия василевсу [2, с. 5, примеч. 1] является опрометчивой ошибкой. В данном письме, как, впрочем, и в ряде поздневизантийских актов, ясно назван «поземельный суд», о котором заходит речь в связи с попытками податных чиновников взыскивать морту с монастырей независимо от того, владели они прежде земельными излишками или нет (см.: [49. № 27]). 


\section{СПИСОК ЛИТЕРАТУРЫ}

1. Быченков, В. М. Институты: сверхколлективные образования и безличные формы социальной субъектности / В. М. Быченков. - М. : РАСН, 1996. $-996 \mathrm{c}$.

2. Византийский земледельческий закон / текст, исслед., коммент. подгот. Е. Э. Липшиц, И. П. Медведев, Е. К. Пиотровская ; под ред. И. П. Медведева. Л. : Наука, 1984. - 280 с.

3. Вин, Ю. Я. Идея социально-экономической общности у византийцев: греко-латинские терминологические параллели / Ю. Я. Вин // Средние века. - М., 2007. - Вып. 68 (3). - С. 145-176.

4. Вин, Ю. Я. Пути к новым знаниям : эксперт. интервью И.П. Медведева для ЭС «Византийское право и акты» / Ю. Я. Вин, М. И. Дробышев // Spicilegium Byzantino-Rossicum : сб. ст. к 80-летию чЛ.-кор. РАНИ. П. Медведева / под ред. Л. А. Герд. М. ; СПб. : Индрик, 2015. - С. 52-58.

5. Каждан, А. П. Деревня и город в Византии IX$\mathrm{X}$ вв. : очерк по истории византийского феодализма / А. П. Каждан.-М. ; Л. : Изд-во АНСССР, 1960.-430 с.

6. Каждан, А. П. К вопросу об особенностях феодальной собственности в Византии VIII-X вв. / А. П. Каждан // Византийский Временник. - 1956. T. $10 .-$ C. $48-65$.

7. Курбатов, Г. Л. Византия: проблемы перехода от античности к феодализму / Г. Л. Курбатов, Г. Е. Лебедева. - Л. : ЛГУ, 1984. - 96 с.

8. Курбатов, Г. Л. История Византии: (От античности к средневековью) / Г. Л. Курбатов. - Л. : Высш. шк., 1984. - 205 с.

9. Липшиц, Е. Э. Византийский земледельческий закон и его судьбы в средневековых балканских государствах / Е. Э. Липшиц. - М. : Изд-во АН СССР, 1966. $-14 \mathrm{c}$.

10. Липшиц, Е. Э. Византийское крестьянство и славянская колонизация (преимущественно по данным Земледельческого закона) / Е. Э. Липшиц // Византийский сборник. - М. ; Л. : Изд-во АН СССР, 1945. - C. 96-143.

11. Липшиц, Е. Э. К истории «Земледельческого закона» в Византии и в средневековых балканских государствах / Е. Э. Липшиц // Византийский Временник. - 1968. - Т. 29. - С. 53-62.

12. Липшиц, Е. Э. Очерки истории византийского общества и культуры: VIII - первая половина IX века / Е. Э. Липшиц. - М. ; Л. : Изд-во АН СССР, 1961. $-482 \mathrm{c}$.

13. Липшиц, Е. Э. Право и суд в Византии IVVIII вв. / Е. Э. Липшиц. - Л. : Наука, 1976. - 230 с.

14. Литаврин, Г. Г. Византийское государство в V-XII вв. / Г. Г. Литаврин // Раннефеодальные государства на Балканах: VI-XII вв. - М. : Наука, 1985. - C. 99-131.
15. Литаврин, Г. Г. Византийское общество и государство в Х-ХІ вв.: Проблемы истории одного столетия: 976-1081 гг. / Г. Г. Литаврин. - М. : Наука, 1977. $-311 \mathrm{c}$.

16. Медведев, И. П. Был ли Константин Арменопул автором «арменопуловской» версии Земледельческого закона? / И. П. Медведев // Византийские очерки. - М. : Наука, 1982. - С. 216-233.

17. Медведев, И. П. «Земледельческий закон» история публикации : эксперт. интервью Ю. Я. Вина с И. П. Медведевым (5 июня 2013 г.). Ч. 1 / И. П. Медведев. - Электрон. мультимедий. дан. - Режим доступа: https://www.youtube.com/watch?v=ljrRDvcPHhs (дата обращения: 10.07.2016). - Загл. с экрана.

18. Медведев, И. П. Правовая культура Византийской империи / И. П. Медведев. - СПб. : Алетейя, 2001. $-576 \mathrm{c}$.

19. Медведев, И. П. Предварительные заметки о рукописной традиции Земледельческого закона. 1. Рукописи X-XII вв. / И. П. Медведев // Византийский Временник. - 1980. - Т. 41. - С. 194-209.

20. Медведев, И. П. Предварительные заметки о рукописной традиции Земледельческого закона. 2. Рукописи XIII-XIV вв. / И. П. Медведев // Византийский Временник. - 1981. - Т. 42. - С. 49-70.

21. Медведев, И. П. Развитие правовой науки / И. П. Медведев // Культура Византии: вторая половина VII - ХІІ в. - М. : Наука, 1989. - С. 216-240.

22. Медведев, И. П. Софийский список «Шестикнижия» Константина Арменопула / И. П. Медведев // Византийский Временник. - 1982. - Т. 43. С. $102-105$.

23. Миронов, Б. Н. Историк и социология / Б. Н. Миронов. - Л. : Наука, 1984. - 174 с.

24. Новаковић, С. Село / С. Новаковић. - Београд : Српска књижовна задруга, 1965.-245 с.

25. Осипова, К. А. Социально-экономические отношения и государственный строй в Византии в конце VII - середине IX в.: Аграрные отношения / К. А. Осипова // История Византии. - М. : Наука, 1967. - T. 2. - C. 13-23.

26. Павлов, А. С. «Книги Законные», содержащие в себе, в древнерусском переводе, византийские законы земледельческие, уголовные, брачные и судебные / А. С. Павлов. - Спб. : Тип. Имп. АН, 1885. - [4], $92 \mathrm{c}$.

27. Пиотровская, Е. К. Византийский «Земледельческий закон» и славяно-русская письменная традиция памятников средневекового права / Е. К. Пиотровская // Труды Отдела древнерусской литературы. - СПб., 2008. - Т. 59. - С. 201-212.

28. Симоновић, 3. Д. Економска политика Византије у законима Ecloge Ton Nomon, Nomos Georgikos, Nomos Rhodian Nautikos, Nomos Stratiotikos / 3. Д. Симоновић. - Ниш : ЕкономикаCBEH, 2007. $-154 \mathrm{c}$. 
29. Слышкин, Г. Г. От текста к символу: Лингвокультурные концепты прецедентных текстов в сознании и дискурсе / Г. Г. Слышкин. - М. : Academia, 2000. - $128 \mathrm{c}$.

30. Сюзюмов, М. Я. Борьба за пути развития феодальных отношений в Византии / М. Я. Сюзюмов // Византийские очерки. - М. : Наука, 1961. -С. 34-63.

31. Сюзюмов, М. Я. К вопросу об особенностях генезиса и развития феодализма в Византии / М. Я. Сюзюмов // Византийский Временник. 1960. - T. 17. - С. 3-16.

32. Сюзюмов, М. Я. О характере и сущности византийской общины по Земледельческому закону / М. Я. Сюзюмов // Византийский Временник. 1956. - T. 10. - С. 27-47.

33. Удальцова, 3. В. Византия и Западная Европа: (типологические наблюдения) / 3. В. Удальцова // Византийские очерки. - М. : Наука, 1977. C. $3-65$.

34. Удальцова, 3. В. К вопросу о генезисе феодализма в Византии / 3. В. Удальцова // Византийские очерки. - М. : Наука, 1971. - С. 3-25.

35. Удальцова, 3. В. Отличительные черты феодальных отношений в Византии (постановка проблемы) / 3. В. Удальцова, К. А. Осипова // Византийский Временник. - 1974. - Т. 36. - С. 3-30.

36. Удальцова, 3. В. Социальные и экономические структуры в поздней Византии: (К вопросу об изменении положения крестьянства в Византийской империи в XIII-XIV вв.) / 3. В. Удальцова, К. В. Хвостова // Взаимосвязь социальных отношений и идеологии в средневековой Европе. - М. : ИВИ АН СССР, 1983. - С. 96-117.

37. Удальцова, 3. В. Типологические особенности феодализма в Византии / 3. В. Удальцова, К. А. Осипова // Проблемы социальной структуры и идеологии средневекового общества. - Л. : Наука, 1974. - Вып. 1. - С. 4-28.

38. Удальцова, 3. В. Формирование феодального крестьянства в Византии: (VII-XI вв.) / 3. В. Удальцова, К. А. Осипова // История крестьянства в Европе: Эпоха феодализма. - М. : Наука, 1985. - Т. 1. C. $387-426$.

39. Angold, M. Church and Society in Byzantium under the Comneni, 1081-1261 / M.Angold. - Cambridge : Cambridge University Press, 1995. - XVI, 604 p.

40. Ashburner, W. The Farmers Law/W. Ashburner // Journal of Hellenic Studies. - 1910. - Vol. 30, part 1.P. 85-108.

41. Chitwood, Z. P. Byzantine Legal Culture under the Macedonian Dynasty, 867-1056 : a diss. presentated to the Fac. of Princeton Univ. in candidacy for the degree of dr of philosophy / Z. P. Chitwood. Princeton, 2012. - XIII, 239 p.

42. Constantini Harmenopuli Manuale legum sive Hexabiblos cum appendicibus et legibus agrariis / ill.
G. E. Heimbach. - Lipsiae: T. O. Weigel, 1851. - XXXII, 1003 p.

43. Das Register des Patriarchats von Konstantinopel / Hrsg. v. H. Hunger, O. Kresten. Wien : Verl. der Österreich. Akad. d. Wissensch., 1981. T1. I. $-624 \mathrm{~S}$.

44. Ferrini, C. Edizione critica del Nó $\mu$ os $\gamma \varepsilon \omega \rho \gamma \iota \kappa o ́ s$ / C. Ferrini // Byzantinische Zeitschrift. Leipzig, 1898. - Bd. 7, Hft. 3-4. - S. 558-571.

45. Gerstel, Sh. E. J. Rural Lives and Landscapes in Late Byzantium: Art, Archaeology, and Ethnography / Sh. E. J. Gerstel. - Cambridge : Cambridge University Press, 2015. - XVIII, $207 \mathrm{p}$.

46. Kazhdan, A. Il Contadino / A. Kazhdan // L'uomo bizantino / a curo di G. Cavalo. - Roma ; Bari : Laterza, 1992. - P. 45-93.

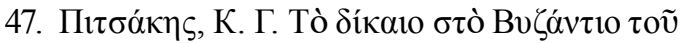

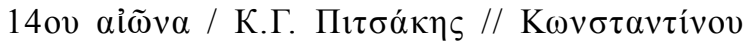

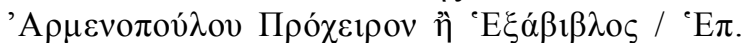

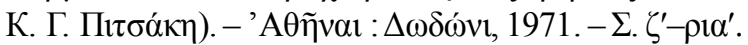

48. Schreiner, P. Stadt und Gesetz-Dorfund Brauch: Versuch einer historischen Volkskunde von Byzanze. Methoden, Quellen, Gegenstände, Beispiele / P. Schreiner // Nachrichten d. Akad. d. Wissensch. zu Göttingen, I. Philolog.-hist. Kl. - Göttingen : Vandenhoeck \& Ruprecht, 2001.-№9.-S. 567(3)-662(96).

49. The Correspondence of Athanasius I Patriarch of Constantinople: Letters to the Emperor Andronicus II, Members of the Imperial Family and Officials / ed. by A.-M. Talbot. - Washington : Dumbarton Oaks Center of Byzantine Studies, 1975. - LII, 467 p.

50. Udal'cova, Z. V. Les structures sociales et économiques dans la Basse-Byzance: Sur la question du changement de la condition de la paysannerie dans l' Empire byzantin aux XIII $-\mathrm{XIV}^{\mathrm{e}}$ siècle/Z. V. Udal'cova, K. V. Chvostova // Jahrbuch der Österreichischen Byzantinistik. - Wien, 1981.-Bd. 31/1.-S. 131-147.

51. Udal'cova, Z. V. Traits distinctifs de rapports féodaux de Byzance: (Mise au point du problème) /

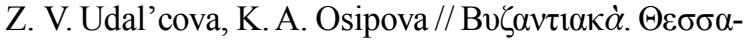

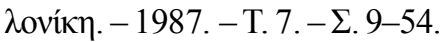

\section{REFERENCES}

1. Bychenkov V.M. Instituty: sverkhkollektivnye obrazovaniya $i$ bezlichnye formy sotsialnoy subyektnosti [The Institutions: Supercollective Formations and Impersonal Forms of Social Subjectivation]. Moscow, RASN Publ., 1996. 996 p.

2. Lipshits E.E., Medvedev I.P., Piotrovskaya E.K., eds. Vizantiyskiy zemledelcheskiy zakon [Byzantine Farmer's Law]. Leningrad, Nauka Publ., 1984. 280 p.

3. Vin Yu.Ya. Ideya sotsialno-ekonomicheskoy obshchnosti u vizantiytsev: grechesko-latinskie terminologicheskie paralleli [Idea of Social-Economic 
Community Among the Byzantins: Greek-Latin Terminological Parallels]. Srednie veka [Middle Ages]. Moscow, 2007, vol. 68 (3), pp. 145-176.

4. Vin Yu.Ya., Drobyshev M.I. Puti k novym znaniyam: expertnoe intervyu I.P. Medvedeva dlya ES "Vizantiyskoe pravo i akty" [The Ways to New Knowledge: Expert Interview by I.P. Medvedev for ES "Byzantine Law and Acts"]. Gerd L.A., ed. Spicilegium Byzantino-Rossicum: sbornik statey k 80-letiyu chlenakorrespondenta RAN I.P. Medvedeva [Spicilegium Byzantino-Rossicum: Collected Articles to the 80th Anniversary of Correspondent Member of RAS I.P. Medvedev]. Moscow; Saint Petersburg, Indrik Publ., 2015, pp. 52-58.

5. Kazhdan A.P. Derevnya i gorod v Vizantii $I X$ $X v$ v.: ocherk po istorii vizantiyskogo feodalizma [The Village and Town in Byzantium in the 9th-10th cc.: Essay on the History of Byzantine Feudalism]. Moscow; Leningrad, Izd-vo AN SSSR, 1960. 430 p.

6. Kazhdan A.P. K voprosu ob osobennostyakh feodalnoy sobstvennosti v Vizantii VIII-X vv. [On Peculiarities of Feudal Property in Byzantium in the 8th10th cc.]. Vizantiyskiy Vremennik, 1956, vol. 10, pp. 48-65.

7. Kurbatov G.L., Lebedeva G.E. Vizantiya: problemy perekhoda ot antichnosti $k$ feodalizmu [Byzantium: the Problems of Transition from Antiquity to the Middle Ages]. Leningrad, LGU Publ., 1984. 96 p.

8. Kurbatov G.L. Istoriya Vizantii: (Ot antichnosti $k$ srednevekovyu) [The History of Byzantium: (From Antiquity to the Middle Ages)]. Leningrad, Vysshaya Shkola Publ., 1984. 205 p.

9. Lipshits E.E. Vizantiyskiy zemledelcheskiy zakon i ego sudby $v$ srednevekovykh balkanskikh gosudarstvakh [Byzantine Farmer's Law and Its Fates in Medieval Balkan States]. Moscow, Izd-vo AN SSSR, 1966. 14 p.

10. Lipshits E.E. Vizantiyskoe krestyanstvo i slavyanskaya kolonizatsiya (preimushchestvenno po dannym Zemledelcheskogo zakona) [Byzantine Peasantry and Slavonian Colonization (Based Mainly on Data of the Farmer's Law)]. Vizantiyskiy sbornik [Byzantine Collection]. Moscow, Leningrad, Izd-vo AN SSSR, 1945, pp. 96-143.

11. Lipshits E.E. $\mathrm{K}$ istorii "Zemledelcheskogo zakona" v Vizantii i v srednevekovykh balkanskikh gosudarstvakh [To the History of the Farmer's Law in Byzantium and in Medieval Balkan States]. Vizantiyskiy Vremennik, 1968, vol. 29, pp. 53-62.

12. Lipshits E.E. Ocherki istorii vizantiyskogo obshchestva i kultury: VIII - pervaya polovina IX veka [The Essays about History of Byzantine Society and Culture: 8 th - the First Half of the 9th c.]. Moscow, Leningrad, Izd-vo AN SSSR, 1961. 482 p.

13. Lipshits E.E. Pravo $i$ sudv Vizantii IV-VIII vv. [The Law and Court in Byzantium in 4th-8th cc.]. Leningrad, Nauka Publ., 1976. 230 p.
14. Litavrin G.G. Vizantiyskoe gosudarstvo v VXII vv. [Byzantine State in 5th-12th cc.]. Rannefeodalnye gosudarstva na Balkanakh: VI-XII vv. [Early Feudal States in the Balkans: 6th-12th cc.]. Moscow, Nauka Publ., 1985, pp. 99-131.

15. Litavrin G.G. Vizantiyskoe obshchestvo $i$ gosudarstvo $v X$-XI vv.: Problemy istorii odnogo stoletiya: 976-1081 gg. [Byzantine Society and State in 10th-11th cc. The Historical Problems of a Single Century: 976-1081]. Moscow, Nauka Publ., 1977.311 p.

16. Medvedev I.P. Byl li Konstantin Armenopul avtorom "armenopulovskoy" versii Zemledelcheskogo zakona? [Was Constantin Harmenopulos the Author of "Harmenopulos' Version" of the Farmer's Law?]. Vizantiyskie ocherki [Byzantine Essays]. Moscow, Nauka Publ., 1982, pp. 216-233.

17. Medvedev I.P. "Zemledelcheskiy zakon" istoriya publikatsii: ekspertnoe intervyu Yu.Ya. Vina s I.P. Medvedevym (5 iyunya 2013 g.). Chast 1 [The Farmer's Law - the History of Publication: Expert Interview of Yu.Ya. Vin and I.P. Medvedev (June 5, 2013). Part 1]. Available at: https://www.youtube.com/ watch?v=ljrRDvcPHhs. (accessed July 10, 2016).

18. Medvedev I.P. Pravovaya kultura Vizantiyskoy imperii [The Law Culture of the Byzantine Empire]. Saint Petersburg, Aleteya Publ., 2001. 576 p.

19. Medvedev I.P. Predvaritelnye zametki o rukopisnoy traditsii Zemledelcheskogo zakona. 1. Rukopisi X-XII vv. [Preliminary Notes on Manuscript Tradition of the Farmer's Law. 1. The Manuscripts of 10th-12th cc.]. Vizantiyskiy Vremennik, 1980, vol. 41, pp. 194-209.

20. Medvedev I.P. Predvaritelnye zametki o rukopisnoy traditsii Zemledelcheskogo zakona. 2. Rukopisi XIII-XIV vv. [Preliminary Notes on Manuscript Tradition of the Farmer's Law. 2. The Manuscripts of 13th-14th cc.]. Vizantiyskiy Vremennik, 1981, vol. 42, pp. 49-70.

21. Medvedev I.P. Razvitie pravovoy nauki [The Development of Law Science]. Kultura Vizantii: vtoraya polovina VII - XII v. [Byzantine Culture: Second Half of 7th -12 th cc.]. Moscow, Nauka Publ., 1989, pp. 216-240.

22. Medvedev I.P. Sofiyskiy spisok "Shestiknizhiya" Konstantina Armenopula [Sofia Copy of Konstantin Harmenopulos" "Hexabiblos"]. Vizantiyskiy Vremennik, 1982, vol. 43, pp. 102-105.

23. Mironov B.N. Istorik i sotsiologiya [The Historian and Sociology]. Leningrad, Nauka Publ., 1984. $174 \mathrm{p}$.

24. Novakovich S. Selo [The Village]. Belgrade, Srpska knjizhovna zadruga, 1965. 245 p.

25. Osipova K.A. Sotsialno-economicheskie otnosheniya i gosudarstvennyy stroy v Vizantii v kontse VII - seredine IX v.: Agrarnye otnosheniya [Social and Economical Relations and State System in Byzantium in the End of 7th - the Middle of 9th c.: the Agricultural 
Relations]. Istoriya Vizantii [History of Byzantium]. Moscow, Nauka Publ., 1967, vol. 2, pp. 13-23.

26. Pavlov A.S. "Knigi Zakonnye", soderzhashchie v sebe, vdrevnerusskom perevode, vizantiyskie zakony zemledelcheskie, ugolovnye, brachnye $i$ sudebnye ["The Law Books", the Old Russian Translation of Which Contains the Agricultural, Criminal, Conjugal and Judicial Laws of Byzantium]. Saint Petersburg, Tip. Imp. AN, 1885. [4], 92 p.

27. Piotrovskaya E.K. Vizantiyskiy "Zemledelcheskiy zakon" i slavyano-russkaya pismennaya traditsiya pamyatnikov srednevekovogo prava [The Byzantine Farmer's Law and Slavic-Russian Written Tradition of Medieval Law Monuments]. Trudy Otdela drevnerusskoy literatury [Works of Department of Old Russian Literature]. Saint Petersburg, 2008, vol. 59, pp. 201-212.

28. Simonovich Z.D. Ekonomska politika Vizantije u zakonima Ecloge Ton Nomon, Nomos Georgikos, Nomos Rhodian Nautikos, Nomos Stratiotikos [Economical Policy of Byzantium in Laws Ecloge Ton Nomon, Nomos Georgikos, Nomos Rhodian Nautikos, Nomos Stratiotikos]. Nish, Ekonomika-SVEN Publ., 2007. 154 p.

29. Slyshkin G.G. Ot teksta $k$ simvolu: Lingvokulturnye kontsepty pretsedentnykh tekstov $v$ soznanii i diskurse [From Text to Symbol: Linguocultural Concepts of Precedent Texts in Consciousness and Discourse]. Moscow, Academiya Publ., 2000. 128 p.

30. Syuzyumov M.Ya. Borba za puti razvitiya feodalnykh otnosheniy v Vizantii [The Struggle for Ways of Development of Feudal Relations in Byzantium]. Vizantiyskie ocherki [Byzantine Essays]. Moscow, Nauka Publ., 1961, pp. 34-63.

31. Syuzyumov M.Ya. K voprosu ob osobennostyakh genezisa i razvitiya feodalizma v Vizantii [On Peculiarities of Genesis and Development of Feudalism in Byzantium]. Vizantiyskiy Vremennik, 1960, vol. 17, pp. 3-16.

32. Syuzyumov M.Ya. O kharaktere i sushchnosti vizantiyskoy obshchiny po Zemledelcheskomu zakonu [On Character and Essence of Byzantine Community According to the Farmer's Law]. Vizantiyskiy Vremennik, 1956, vol. 10, pp. 27-47.

33. Udaltsova Z.V. Vizantiya i Zapadnaya Evropa: (tipologicheskie nablyudeniya) [Byzantium and the Western Europe: (Typological Observations)]. Vizantiyskie ocherki [Byzantine Essays]. Moscow, Nauka Publ., 1977, pp. 3-65.

34. Udaltsova Z.V. K voprosu o genezise feodalizma v Vizantii [On Genesis of Feudalism in Byzantium]. Vizantiyskie ocherki [Byzantine Essays]. Moscow, Nauka Publ., 1971, pp. 3-25.

35. Udaltsova Z.V., Osipova K.A. Otlichitelnye cherty feodalnykh otnosheniy v Vizantii (postanovka problemy) [The Distinctive Features of Feudal
Relations in Byzantium (Problem Statement)]. Vizantiyskiy Vremennik, 1974, vol. 36, pp. 3-30.

36. Udaltsova Z.V., Khvostova K.V. Sotsialnye i ekonomicheskie struktury v pozdney Vizantii: ( $\mathrm{K}$ voprosu ob izmenenii polozheniya krestyanstva $\mathrm{v}$ Vizantiyskoy imperii v XIII-XIV vv.) [The Social and Economical Structures in Late Byzantium: (On the Change of Position of Peasantry in Byzantine Empire in 13th-14th cc.)]. Vzaimosvyayz sotsialnykh otnosheniy $i$ ideologii v srednevekovoy Evrope [Interconnection of Social Relations and Ideology in the Mediaeval Europe]. Moscow, IVI AN SSSR, 1983, pp. 96-117.

37. Udaltsova Z.V., Osipova K.A. Tipologicheskie osobennosti feodalizma v Vizantii [The Typological Peculiarities of Feudalism in Byzantium]. Problemy sotsialnoy struktury $i$ ideologii srednevekovogo obshchestva [The Problems of Social Structure and Ideology of Mediaeval Society]. Leningrad, Nauka Publ., 1974, iss. 1, pp. 4-28.

38. Udaltsova Z.V., Osipova K.A. Formirovanie feodalnogo krestyanstva v Vizantii: (VII-XI vv.) [The Formation of Feudal Peasantry in Byzantium: (7th11th cc.)]. Istoriya krestyanstva v Evrope: Epokha feodalizma [The History of Peasantry in Europe: Epoch of Feudalism]. Moscow, Nauka Publ., 1985, vol. 1, pp. 387-426.

39. Angold M. Church and Society in Byzantium under the Comneni, 1081-1261. Cambridge, Cambr. Univ. Pr., 1995. XVI, 604 p.

40. Ashburner W. The Farmer's Law. Journal of Hellenic Studies, 1910, vol. 30, part 1, pp. 85-108.

41. Chitwood Z.P. Byzantine Legal Culture under the Macedonian Dynasty, 867-1056: A Dissertation Presented to the Faculty of Princeton University in Candidacy for the Degree of Doctor of Philosophy. Princeton, 2012. XIII, 239 p.

42. Heimbach G.E., ed. Constantini Harmenopuli Manuale legum sive Hexabiblos cum appendicibus et legibus agrariis. Lipsiae, T.O. Weigel. 1851, XXXII, $1003 \mathrm{p}$.

43. Hunger H., Kresten O., eds. Das Register des Patriarchats von Konstantinopel. Wien, Verl. der Österreich. Akad. d. Wissensch., 1981, T1. I. 624 S.

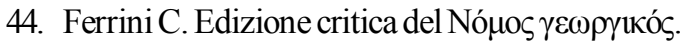
Byzantinische Zeitschrift. Leipzig, 1898, Bd. 7, Hft. 3-4, S. 558-571.

45. Gerstel Sh.E.J. Rural Lives and Landscapes in Late Byzantium: Art, Archaeology, and Ethnography. Cambridge, Cambr. Univ. Pr., 2015. XVIII, 207 p.

46. Kazhdan A. Il Contadino. Cavalo G, ed. L'uomo bizantino. Roma, Bari, Laterza, 1992, pp. 45-93.

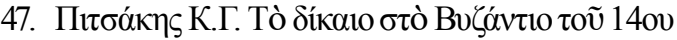

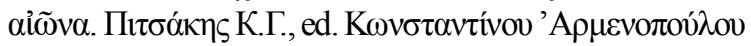

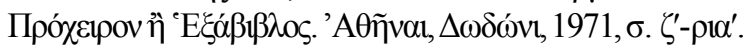

48. Schreiner P., Stadt und Gesetz - Dorf und Brauch: Versuch einer historischen Volkskunde von 


\section{ИСТОРИЯ, КУЛЬТУРА, ПРАВО В ВИЗАНТИЙСКИХ ПРОВИНЦИЯХ}

Byzanze. Methoden, Quellen, Gegenstände, Beispiele. Nachrichten d. Akad. d. Wissensch. zu Göttingen, I. Philolog.-hist. Kl. Göttingen, Vandenhoeck \& Ruprecht, 2001, No. 9, S. 567(3)-662(96).

49. Talbot A.-M., ed. The Correspondence of Athanasius I Patriarch of Constantinople: Letters to the Emperor Andronicus II, Members of the Imperial Family and Officials. Washington, Dumbarton Oaks Center of Byzantine Studies, 1975. LII, 467 p.
50. Udaltsova Z.V., Chvostova K.V. Les structures sociales et économiques dans la Basse-Byzance: Sur la question du changement de la condition de la paysannerie dans 1'Empire byzantin aux $\mathrm{XIII}^{\mathrm{e}}-$ $\mathrm{XIV}^{\mathrm{e}}$ siècle. Jahrbuch der Österreichischen Byzantinistik. Wien, 1981, Bd. 31/1, S. 131-147.

51. Udaltsova Z.V., Osipova K.A. Traits distinctifs de rapports féodaux de Byzance: (Mise au point du problème).

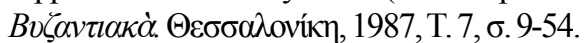

\section{Information About the Author}

Yury Ya. Vin, Candidate of Sciences (History), Senior Researcher, Institute of World History, Russian Academy of Sciences, Prosp. Leninskiy, 32a, 991119 Moscow, Russian Federation, hkn@igh.ras.ru.

\section{Информация об авторе}

Юрий Яковлевич Вин, кандидат исторических наук, старший научный сотрудник Института всеобщей истории РАН, Ленинский просп., 32a, 991119 г. Москва, Российская Федерация, hkn@igh.ras.ru. 